Check for updates

Bogotá, Colombia

lukestephentaylor@gmail.com Cite this as: BMJ 2020;370:m3319 http://dx.doi.org/10.1136/bmj.m3319 Published: 01 September 2020

\section{How Latin America is fighting covid-19, for better and worse}

\section{Covid-19 continues to rip through Latin America despite some of the world's longest lockdowns. From denial to swift action, Luke Taylor looks at the myriad strategies deployed}

Luke Taylor

Though home to around $8 \%$ of the world's population, Latin America accounts for over a quarter of all confirmed covid-19 cases and nearly a third of all related deaths. The number of confirmed infections in Latin America has exceeded six and a half million as deaths close in on the quarter of a million mark. ${ }^{1}$

The Pan American Health Organization (PAHO) has pleaded for governments to double down on measures to contain the virus's spread as it shows "no signs of slowing down." The region's largest countries, Brazil and Mexico, have not heeded the call. Other nations have, however, followed World Health Organization recommendations closely for more than four months.

“The region's covid-19 experiences demonstrate wide variation across countries," says Michael Touchton at the University of Miami's Covid-19 Policy Observatory for Latin America. "Brazil and Mexico have some of the worst outbreaks in the world, while Uruguay's experience ranks with the least deadly in Asia or Europe.”

\section{Populism marks the epicentre}

The number of cases recorded in Brazil has reached over three million, second in the world only to the

US. Brazil's president, Jair Bolsonaro, has been widely criticised for playing down the threat of covid-19 and not taking action to slow its spread such as enforcing nationwide lockdowns or the use of face masks.

Mexico isn't far behind though. With more than 60 ooo recorded covid-19 deaths it is behind only the US and Brazil in overall mortality, and it's likely there has been a severe undercount.

Like Bolsonaro, President Andrés Manuel López Obrador has been criticised for trivialising the virus, proudly showing off amulets which he said would be his "protective shield" against covid-19 in a press conference. He has not worn a face mask or followed social distancing recommendations, confusing the public and undermining the public health response, say critics.

But though the president has mismanaged the public health crisis, Mexico's Ministry of Health has reacted well, maximising the capacity of its poorly equipped health system, says Samuel Ponce de León, an infectious disease specialist at the National Autonomous University of Mexico. "The response has been well organised considering the health system in Mexico," he says. "If you compare health systems of OECD countries we are at the bottom for the number of hospitals, number of beds, number of physicians, number of intensive care beds, and so on. Even compared with other Latin American countries we are not doing well."

Despite the president's stance, Mexico succeeded in shutting down all but essential economic activity on 23 March and began preparing its staff and hospitals for an influx of patients. It began relaxing restrictions on 1 June as the economic slump was biting. In the following week, however, confirmed cases more than doubled from 93435 to $275003 .^{3}$

The country faces the same key challenge as most of the continent: keeping people at home when over half of its workforce ${ }^{4}$ belongs to the informal economy (that which is not taxed or regulated by the state). Its population, though young, is the most obese in the world $-72.5 \%$ of adults are classified overweight or obese ${ }^{5}$-meaning it is at high risk of severe symptoms.

\section{Not losing, not winning}

Most South American countries have, however, followed WHO recommendations far more closely. Bolivia, Colombia, Ecuador, and Peru began locking down as their first covid-19 cases were confirmed in March, implementing some of the longest and strictest lockdowns in the world.

Yet they are of growing concern. The virus there shows "no signs of slowing down," PAHO's director, Carissa Etienne, told a press conference in late July.

Colombia had recorded over 500 ooo cases by the end of August, ${ }^{1}$ joining Brazil, Mexico, Peru, and Chile in the 10 countries with the most recorded infections in the world. The Andean nation has seen no sharp peak in reported cases or mortalities, rather a slow and steady slide into a public health crisis. Hospitals in the capital of Bogotá bordered on capacity during July and August, though lockdowns were yet to be fully lifted.

The Colombian government has been criticised by doctors for failing to implement a strategy beyond indefinite lockdowns. Fernanda Gutiérrez, a virologist at Bogotá's Javeriana University, told The BMJ, “The confinement has been extended to reduce infections-not only because there isn't enough hospital infrastructure but because it's expected that there will be a drug that can be used to treat infections or a vaccine that prevents the virus and thus we won't have to suffer the 'tsunamis' experienced in Europe."

But with limited health infrastructure and expertise for testing and tracing, others praise the government's strategy of buying time while it boosts healthcare capacity. Colombia's intensive care capacity has increased by $40 \%$ since the crisis began. ${ }^{6}$ 
"Though cases continue to increase, case mortalities have remained relatively low at 1.9\%, a good example of best practice," says Marcos Espinal, director of the Department of Communicable Diseases and Health Analysis at PAHO. "This is the purpose of mitigation, to slow the outbreak so the health system can cope."

Colombia, like Peru, is a microcosm of the problems that offset the early warning Latin America received after seeing the situation in Europe. Around half of Colombia's workforce make a living in the informal economy and its populations are diverse and unequal-ranging from those living in the Andean megacity of Bogota to the indigenous communities in the Sierra Nevada mountain range to Afro-Colombian communities on the Pacific coast.

"There are several factors in Latin America that make this pandemic more difficult: inequality, belts of poverty surrounding big cities, informal economies, and difficult areas of access," Espinal says.

\section{Success stories}

But while most South American countries have lost control of the virus, some have managed to keep infections low. Though facing less severe structural challenges than their neighbours, their public health responses-with rigorous testing at their core-have been effective in keeping covid-19 at bay.

Cuba swiftly sent its army of over 100 ooo doctors ${ }^{7}$-the highest number per patient ratio in the world at 8.19 per 1000-door to door educating and testing the public. Its government has been swift and uncompromising in sending anyone suspected of infection into isolation. It had reported 3682 cases and 91 deaths as of 24 August. ${ }^{1}$

Costa Rica has also kept its number of infections and fatalities relatively low at 25057 and 263, respectively, thanks to rigorous testing and tracing. It has tested 22.45 Costa Ricans for every $1000 .^{8}$

Perhaps most impressive is the response of Uruguay, where 45.69 people have been tested for covid-19 for every 1000 inhabitants. Its government acted swiftly in closing borders, schools, and public events on 13 May while ramping up its testing and tracing facilities. "The result is what lockdowns were supposed to allow in other countries, but generally did not: time to mobilise the health system-a robust one in Uruguay's case-for a nationally led, consistent response," says Touchton.

Uruguay reaped the rewards of extensive, targeted testing, including the use of a contact tracing app developed by local software companies which reportedly had 350 ooo downloads in its first three months. 9 "Actively searching for cases and the use of polymerase chain reaction tests allowed them to identify cases and take the necessary means of quarantine and isolation," Escalante says.

Surprisingly, Uruguay never enforced lockdowns. President Luis Lacalle Pou asked, rather than ordered, people to stay home for their own wellbeing and that of fellow citizens.

Lessons could be learnt from the effectiveness of this liberal strategy as most of Latin America sent its armies onto the streets only for infections to surge. There are myriad factors at play, from public trust in Uruguay's institutions and politics to its education system, but for Escalante, "It's the level of information available, education, and civil duty.”

He praised the "one single, clear message" from the government that gave clarity to the public rather than the confusion caused by political disunity that has been seen elsewhere across the Americas.
Competing interests: I have read and understood BMJ policy on declaration of interests and have no relevant interests to declare.

PAHO. Cumulative covid-19 cases. https://ais.paho.org/phip/viz/COVID19Table.asp.

2 Laing A, Sigal L. Coronavirus pandemic "showing no signs of slowing down" in Americas-PAHO. Reuters. 21 July 2020. https://uk.reuters.com/article/uk-health-coronavirus-who-americas/coronavirus-pandemic-showing-no-signs-of-slowing-down-in-americas-paho-idUKKCN24M2CV.

3 Mahase E. Covid-19: Deaths in Mexico triple since reopening began in June. BMJ2020;370:m2753. doi: 10.1136/bmj.m2753 pmid: 32646860

4 OECD. Presentation of the 2019 economic survey of Mexico. 2 May 2019. www.oecd.org/mexico/2019-economic-survey-of-mexico-may-2019.htm.

5 Unicef Mexico. What are we waiting for? 4 March 2020. www.unicef.org/stories/what-are-wewaiting-for-obesity-mexico.

6 Armario C. Colombia's long virus lockdown fuels anxiety and depression. AP News. 5 August 2020. https://apnews.com/0e47524f0453c382c8c652de340b178c.

7 Cuba has more than 100000 active doctors, according to minister. OnCuba News. 22 July 2020. https://oncubanews.com/en/cuba/cuba-has-more-than-100000-active-doctors-according-tominister.

8 Our World in Data. Total covid-19 tests per 1000 people. https://ourworldindata.org/grapher/fulllist-cumulative-total-tests-per-thousand-map.

9 Coronavirus UY: Cómo funciona la aplicación uruguaya que alerta sobre casos de covid-19. 25 June 2020. El Pais. www.elpais.com.uy/multimedia/coronavirus-uy-funciona-aplicacion-uruguayaalerta-casos-covid.html. 